\title{
PENGARUH KNO 3 DAN PERBEDAAN UMUR BIBIT PADA PERTUMBUHAN KELAPA SAWIT (Elaeis guineensis Jacq.) DI MAIN-NURSERY
}

\section{EFFECT OF KNO3 APPLICATIONS AND DIFFERENT AGE OF SEEDLINGS ON THE GROWTH OF OILPALM (Elaeis guineensis Jacq.) IN MAIN-NURSERY}

\author{
Kresna Shifa Usodri*, Bambang Utoyo, Dimas Prakoswo Widiyani \\ Jurusan Budidaya Tanaman Perkebunan, Politeknik Negeri Lampung, Bandar Lampung \\ *Email:kresna@polinela.ac.id \\ * Corresponding Author, Diterima: 08 Juli 2021, Direvisi: 10 Ags. 2021, Disetujui: 21 Sep. 2021
}

\section{ABSTRACT}

Main-nursery can produce quality seeds if during the process good maintenance is carried out. One way that can be done is to provide adequate nutrient fulfillment and the appropriate transplanting age phase from pre-nursery to main-nursery. Therefore, it is necessary to test plants using different ages of transplanting seedlings with the addition of KNO3. The method applied in this study used a two-factor factorial design (4x5). The first factor of treatment was the age of oil palm seedlings 45 days after planting (U1), 60 days after planting (U2), 75 days after planting (U3), and 90 days after planting (U4). The second factor is the recommended dosage of Compound NPK Fertilizer (P1), 1\% KNO3 Fertilizer (P2), 2\% KNO3 Fertilizer (P3), 3\% KNO3 Fertilizer (P4), and 4\% KNO3 Fertilizer (P5) with the addition of Compound NPK Fertilizer. 0.25 recommended dose for treatment P2, P3, P4, P5. Observational data will be analyzed by $F$ test at level $=5 \%$. If the results of the analysis of variance are significant, it will be continued with the least significant difference test (LSD) at level $\alpha=5 \%$. The results showed that the use of transplanting oil palm seedlings can be done at the age of 45 days after planting and the application of $4 \%$ KNO3 fertilizer with 0.25 recommended dose of compound NPK can optimize growth in oil palm nurseries at a more efficient cost.

Keywords: Fertilization, $\mathrm{KNO}_{3}$, nursery, oil palm.

\begin{abstract}
ABSTRAK
Pembibitan di main-nursery dapat menghasilkan bibit yang berkualitas apabila selama prosesnya dilakukan pemeliharaan yang baik. Salah satu cara yang dapat dilakukan adalah dengan memberikan pemenuhan unsur hara yang cukup serta fase umur pindah tanam yang sesuai dari pre-nursery ke main-nursery. Oleh sebab itu, perlu dilakukan uji tanaman dengan menggunakan umur bibit pindah tanam yang berbeda dengan penambahan $\mathrm{KNO}_{3}$. Penelitian ini menggunakan rancangan faktorial dua faktor $(4 x 5)$. Faktor pertama perlakuan adalah umur bibit kelapa sawit 45 hari setelah tanam $\left(\mathrm{U}_{1}\right), 60$ hari setelah tanam $\left(\mathrm{U}_{2}\right), 75$ hari setelah tanam $\left(\mathrm{U}_{3}\right)$, dan 90 hari setelah tanam $\left(\mathrm{U}_{4}\right)$. Faktor ke dua berupa dosis pupuk yang terdiri dari pupuk NPK Majemuk rekomendasi $\left(\mathrm{P}_{1}\right)$, Pupuk $\mathrm{KNO}_{3} 1 \%\left(\mathrm{P}_{2}\right)$, Pupuk $\mathrm{KNO}_{3} 2 \%\left(\mathrm{P}_{3}\right)$, Pupuk $\mathrm{KNO}_{3} 3 \%\left(\mathrm{P}_{4}\right)$, dan Pupuk $\mathrm{KNO}_{3} 4 \%\left(\mathrm{P}_{5}\right)$ dengan penambahan pupuk NPK Majemuk 0,25 dosis rekomendasi pada perlakuan P2, P3, P4, P5. Data hasil pengamatan dianalisis dengan uji $\mathrm{F}$ pada taraf $\alpha=5 \%$. Jika hasil analisis ragam nyata maka dilanjutkan dengan uji
\end{abstract}


beda nyata terkecil (BNT) pada tarafá $=5 \%$. Hasil penelitian menunjukkan bahwa pemindahtanaman bibit kelapa sawit dapat dilakukan pada umur 45 hari setelah tanam dan pemberian pupuk $\mathrm{KNO}_{3}$ konsertrasi $4 \%$ dengan 0,25 dosis rekomendasi NPK majemuk dapat mengoptimalkan pertumbuhan pada pembibitan kelapa sawit dengan biaya yang lebih efisien.

Kata kunci : Kelapa sawit, $\mathrm{KNO}_{3}$, pembibitan, pemupukan.

\section{PENDAHULUAN}

Kelapa Sawit (Elaeis guineensis Jacq) merupakan salah satu komoditas perkebunan yang memiliki nilai ekonomis yang tinggi. Hasil olahan dari tanaman tersebut merupakan produk minyak sawit (CPO) dan minyak inti sawit (KPO) yang menjadi primadona dibandingkan dengan tanaman perkebunan lainnya. Tingginya nilai ekonomis dari hasil jual produk tersebut menimbulkan peningkatan industri kelapa sawit dari tahun ke tahun. Hal tersebut dapat dilihat dari pertambahan luah areal dari tahun 2017 yaitu 14.048.722 ha menjadi 14.677.560 ha pada tahun 2019 (Direktorat Jendral Perkebunan, 2020). Tingginya pertambahan luar areal tersebut akan diikuti pula meningkatnya permintaan bibit yang berkualitas yang semakin bertambah.

Bibit kelapa sawit yang berkualitas dapat dihasilkan melalui sistem pembibitan doble stage (pembibitan dua tahap) karena memiliki kelibihan dalam seleksi bibit yang ketat dan pemeliharan di pre-nursery yang cukup mudah (Fauzi et al., 2012). Akan tetapi, pada tahap main-nursery perlu pengelolaan yang baik dalam hal pemenuhan unsur hara yang cukup dan berimbang untuk mengoptimalkan pertumbuhannya. Salah satu unsur hara yang penting dalam proses pertumbuhan tanaman adalah Nitrogen $(\mathrm{N})$ (Kurniawan et al., 2017). Pemberian unsur hara nitrogen yang cukup dan berimbang juga dapat mengoptimalkan pertumbuhan tanaman pada saat fase vegetatif(Mastur et al., 2015). Selain itu, unsur Kalium(K) juga sangat dibutuhkan bagi tanaman, karena dapat mengoptimalkan penyerapan unsur nitrogen dan phospat (Brhane et al., 2017; Du et al., 2017; Zhang et al., 2015). Fauzi dan Putra (2019) menambahkan bahwa pemberian kalium dapat meningkatkan penyerapan unsur hara mikro lainnya, salah satunya yakni Mg. Oleh sebab itu, perlunya pemupukan yang berimbang terutama penambahan unsur $\mathrm{N}$ dan $\mathrm{K}$ pada pembibitan kelapa sawit untuk mengoptimalkan pertumbuhannya.

Pemupukan pada pembibitan kelapa sawit sistem doble stage biasanya memakai pupuk NPK Majemuk untuk mencukupi kebutuhan hara tanaman (Sukmawan et al. 2018). Maruli et al. (2012) menambahkan bahwa pemakaian pupuk NPK Majemuk dengan penambahan kiserit mampu untuk mengoptimalkan pertumbuhan vegetatiftanaman. Akan tetapi, pemakaian pupuk dan biaya pemupukan yang dikeluarkan pada saat pembibitan terutama pada fase main-nursery relatif tinggi. Oleh sebab itu, perlu adanya alternatif pemupukan yang dapat mengoptimalkan pertumbuhan tanaman dan menghemat biaya pemupukan. Alternatifyang dapat digunakan adalah dengan menggunakan pupuk $\mathrm{KNO}_{3}$ dan mengurangi 
dosis pemakaian pupuk NPK Majemuk.

Pemupukan $\mathrm{KNO}_{3}$ terbukti mampu untuk mengoptimalkan pertumbuhan bibit kelapa sawit. Hal ini sesuai dengan pernyataan Usodri dan Utoyo (2021), bahwa pemberian $\mathrm{KNO}_{3}$ mampu untuk menjadi alternatif pemupukan dalam mengoptimalkan pertumbuhan bibit kelapa sawit fase pre-nursery. Saputra et al, (2017) menambahkan bahwa pemberian $\mathrm{KNO}_{3}$ dengan konsentrasi yang berbeda mampu untuk mematahkan dormansi benih kelapa sawit serta memacu pertumbuhan bibit di pre-nursery. Aplikasi pupuk $\mathrm{KNO}_{3}$ juga mampu untuk meningkatkan pertumbuhan serta hasil tanaman tembakau varietas Deli (Siregar et al., 2018) dan tembakau varietas Virginia (Hutapea et al., 2014).

Selain dari pemberian unsur hara, waktu pemindahan bibit juga perlu diperhatikan dalam pembibitan kelapa sawit. PPKS (2019) menyatakan bahwa umur bibit yang baik dalam proses pindah tanam dari pre-nursery ke main-nursery adalah 3 bulan setelah tanam di pre-nursery. Akan tetapi, proses umur bibit pindah tanam dapat dilakukan lebih awal dengan syarat air dan unsur hara tercukupi (PPKS, 2019).

Oleh sebab itu, perlu dilakukan uji parameter tumbuh untuk untuk mendapatkan fase umur bibit pindah tanam dan konsentrasi $\mathrm{KNO}_{3}$ yang sesuai dalam mengoptimalkan pertumbuhan di main-nursery.

\section{BAHAN DAN METODE}

\section{Alat dan Bahan}

Alat-alat yang akan digunakan dalam penelitian antara lain: meteran, jangka sorong, SPAD-502 Plus (Konica Minolta, Jepang), CID Bioscience portable laser leaf area meter, timbangan, ember, koret, polibeg dan gelas ukur. Bahan yang akan digunakan dalam penelitian antara lain: bibit kelapa sawit DxP varietas Simalungun(PPKS, Medan), plastik lembaran, pupuk NPK Majemuk 16:16:16 dan Pupuk $\mathrm{KNO}_{3}$.

\section{Waktu dan Tempat Penelitian}

Penelitian dilaksanakan pada April sampai dengan Oktober 2020. Lokasi penelitian di Usaha Pembibitan Kelapa Sawit Politeknik Negeri Lampung, Rajabasa, Bandar Lampung. Pengukuran sifat kimia tanah dilakukan di Laboratorium Analisis Kimia Politeknik Negeri Lampung.

\section{Desain Percobaan}

Rancangan percobaan yang digunakan adalah rancangan acak faktorial (RAF) 4 x 5 dengan lima ulangan. Faktor pertama perlakuan adalah umur bibit kelapa sawit pindah tanam yang terdiri dari empat stadia, yaitu 45 hari setelah tanam di pre-nursery $\left(\mathrm{H}_{1}\right)$, 60 hari setelah tanam di pre-nursery $\left(\mathrm{H}_{2}\right), 75$ hari setelah tanam di pre-nursery $\left(\mathrm{H}_{3}\right)$, dan 90 hari setelah tanam di pre-nursery $\left(\mathrm{H}_{4}\right)$. Faktor ke dua merupakan dosis pupuk yang terdiri atas lima taraf, meliputi dosis pupuk NPK Majemuk rekomendasi $\left(\mathrm{P}_{1}\right)$, Pupuk $\mathrm{KNO}_{3}$ konsentrasi $1 \%$ dengan 0,25 dosis pupuk NPK Majemuk rekomendasi $\left(\mathrm{P}_{2}\right)$, Pupuk $\mathrm{KNO}_{3}$ konsentrasi 2\% dengan 0,25 dosis pupuk NPK Majemuk rekomendasi $\left(\mathrm{P}_{3}\right)$, Pupuk $\mathrm{KNO}_{3}$ konsentrasi 3\% dengan 0,25 dosis pupuk NPK Majemuk rekomendasi $\left(\mathrm{P}_{4}\right)$, dan Pupuk $\mathrm{KNO}_{3}$ konsentrasi 4\% dengan 0,25 dosis pupuk NPK Majemuk rekomendasi $\left(\mathrm{P}_{5}\right)$. Data hasil pengamatan dianalisis dengan uji $\mathrm{F}$ pada taraf $\alpha=5 \%$. Jika hasil analisis ragam nyata maka dilanjutkan dengan uji beda nyata terkecil (BNT) pada taraf $\alpha=5 \%$. 


\section{Pelaksanaan Penelitian}

\section{Penanaman Bibit}

Bibit yang digunakan untuk proses pindah tanam disiapkan terlebih dahulu sesuai dengan perlakuan yang diterapkan. Kemudian polibeg yang sudah diisi dengan media tanam disusun dengan jarak tanam segitiga sama sisi $70 \mathrm{~cm} \times 70 \mathrm{~cm}$ x $70 \mathrm{~cm}$. Polibeg tersebut dibuat lubang tanam dengan menggunakan ponjo untuk memudahkan proses penanaman bibit. Setelah luban tanam dibuat, maka bibit yang telah disiapkan ditanam dalam lubang tanam. Setelah itu, media tanam tersbut dipadatkan dan disiram air.

Pembuatan Larutan dan aplikasi $\mathrm{KNO}_{3}$

Pupuk $\mathrm{KNO}_{3}$ ditimbang dengan takaran 10, 20,30 , dan $40 \mathrm{~g}$. Setelah ditimbang, pupuk tersebut dilarutkan pada air aquades dengan volume 1 liter. Aduk pupuk tersebut hingga larut dan menyatu dengan air aquades. Barulah kemudian pupuk bisa diaplikasikan sesuai dengan konsentrasi dengan cara disiram di sekitar area bibit dalam polibeg.

\section{Pemeliharaan}

Kegiatan pemeliharaan meliputi penyiraman, penyiangan gulma, dan pengendalian hama penyakit tanaman. Penyiraman dilakukan pada pagi dan sore hari dengan volume penyiraman 500 $\mathrm{ml}$ air apabila tidak hujan. Penyiangan gulma dilakukan tiga hari sekali dengan cara dicabut dan menggunakan koret untuk membersihkan gulma antar polibag. Pengendalian hama menggunakan insektisida dengan bahan aktif emamektin benzoat. Pengendalian penyakit dengan fungisida berbahan aktif propineb $70 \%$ dan zinc.

\section{Pengamatan}

Untuk mendapatkan data pada penelitian ini dilakukan pengamatan pada 200 hari setelah pindah tanam terhadap:

1. Tinggi bibit, diukur dari batas leher akar sampai ke ujung daun tertinggi menggunakan meteran.

2. Diameter bibit, diukur pada pangkal batang bibit dengan menggunakan jangka sorong.

3. Jumlah pelepah, diukur dengan menghitung langsung jumlah pelepah yang terbentuk sempurna secara visual.

4. Tingkat kehijauan daun diamati dengan SPAD-502 Plus pada daun ke tiga dari daun termuda dengan cara mengambil data di bagian pangkal, tengah dan ujung daun kemudian dijumlah dan dirata - rata.

5. Luas daun diukur dengan menggunakan alat Portable Leaf Area Meter, CID-Bioscience pada daun ke tiga dari tunas daun termuda tanpa mencabut atau memisahkan daun dari bibit.

\section{HASIL DAN PEMBAHASAN}

Hasil penelitian menunjukkan bahwa aplikasi $\mathrm{KNO}_{3}$ memberikan pengaruh yang nyata pada pertumbuhan bibit kelapa sawit yang berbeda umur pindah tanam. Terdapat interaksi yang nyata antara pemberian konsentrasi $\mathrm{KNO}_{3}$ dengan perbedaan umur bibit pindah tanam pada keseluruhan variabel pertumbuhan yang diamati. Rekapituasi hasil analisis ragam data penelitian untuk pertumbuhan bibit kelapa sawit ditampilkan pada Tabel 1.

Hasil uji lanjut(BNT 5\%) menunjukkan bahwa pemindahan bibit umur 45 hari setelah tanam (HST) dengan pemberian pupuk $\mathrm{KNO}_{3} 4 \%$ ditambah 0,25 dosis rekomendasi pupuk NPK Majemuk $\left(\mathrm{H}_{1} \mathrm{P}_{5}\right)$ menunjukkan nilai parameter tumbuh yang lebih besar 
Tabel 1. Rekapitulasi hasil ANOVA pengaruh aplikasi $\mathrm{KNO}_{3}$ dan penambahan 0,25 dosis rekomendasi pupuk NPK Majemuk dengan umur bibit pindah tanam pada pengamatan 200 hari setelah tanam.

\begin{tabular}{lccc}
\hline \multirow{2}{*}{ Variabel Pengamatan } & \multicolumn{3}{c}{ Signifikasi (Nilai F - Hitung perlakuan) } \\
\cline { 2 - 4 } & Umur Bibit $(\mathrm{H})$ & Aplikasi Pupuk (P) & Interaksi \\
\hline Tinggi Bibit $(\mathrm{cm})$ & $337,16^{* *}$ & $135,10^{* *}$ & $14,92^{* *}$ \\
Diameter Bibit (mm) & $26,85^{* *}$ & $28,79^{* *}$ & $4,27 * *$ \\
Luas Daun $(\mathrm{cm})$ & $30,07^{* *}$ & $289,31^{* *}$ & $7,67 * *$ \\
Tingkat Kehijauan Daun & $10,65^{* *}$ & $17,19^{* *}$ & $4,20^{* *}$ \\
Jumlah Pelepah & $17,81^{* *}$ & $37,98^{* *}$ & $5,84 * *$ \\
\hline
\end{tabular}

Keterangan : $* *=$ berpengaruh sangat nyata pada $\alpha=1 \%, *=$ berpengaruh sangat nyata pada $\alpha=5 \%$.

Tabel 2. Rata - rata tinggi bibit kelapa sawit $(\mathrm{cm})$ pada pengamatan 200 hari setelah pindah tanam.

\begin{tabular}{cccccc}
\hline \multirow{2}{*}{ Umur Bibit } & \multicolumn{5}{c}{ Pemupukan } \\
\cline { 2 - 6 } & $\mathrm{P} 1$ & $\mathrm{P} 2$ & $\mathrm{P} 3$ & $\mathrm{P} 4$ & $\mathrm{P} 5$ \\
\hline \multirow{2}{*}{$45 \mathrm{HST}$} & $56,53 \mathrm{~d}$ & $60,90 \mathrm{c}$ & $63,40 \mathrm{~b}$ & $64,93 \mathrm{~b}$ & $67,17 \mathrm{a}$ \\
& $\mathrm{A}$ & $\mathrm{A}$ & $\mathrm{A}$ & $\mathrm{A}$ & $\mathrm{A}$ \\
\multirow{2}{*}{$60 \mathrm{HST}$} & $49,67 \mathrm{~d}$ & $53,00 \mathrm{c}$ & $56,10 \mathrm{~b}$ & $57,43 \mathrm{~b}$ & $59,43 \mathrm{a}$ \\
& $\mathrm{B}$ & $\mathrm{B}$ & $\mathrm{B}$ & $\mathrm{B}$ & $\mathrm{B}$ \\
\multirow{2}{*}{$75 \mathrm{HST}$} & $47,93 \mathrm{~d}$ & $50,53 \mathrm{c}$ & $53,53 \mathrm{~b}$ & $54,47 \mathrm{~b}$ & $56,20 \mathrm{a}$ \\
& $\mathrm{C}$ & $\mathrm{C}$ & $\mathrm{C}$ & $\mathrm{C}$ & $\mathrm{B}$ \\
\multirow{2}{*}{$90 \mathrm{HST}$} & $49,80 \mathrm{c}$ & $51,83 \mathrm{~b}$ & $52,73 \mathrm{~b}$ & $53,73 \mathrm{~b}$ & $55,60 \mathrm{a}$ \\
& $\mathrm{B}$ & $\mathrm{BC}$ & $\mathrm{C}$ & $\mathrm{C}$ & $\mathrm{C}$ \\
\hline BNT & \multicolumn{5}{c}{1,64} \\
\hline
\end{tabular}

Keterangan : Dua nilai tengah yang diikuti oleh huruf yang sama dinyatakan tidak berbeda nyata menurut uji BNT pada taraf $\alpha=5 \%$. Huruf kecil dibaca mendatar dan huruf besar dibaca menurun.

jika dibandingkan dengan perlakuan lainnya. Interaksi yang timbul tersebut dikarenakan peranan dari pupuk $\mathrm{KNO}_{3}$ yang memiliki unsur hara $\mathrm{N}$ dan $\mathrm{K}$ yang sangat baik dalam pertumbuhan vegetatif tanaman.

Interaksi antara umur bibit pindah tanam dengan aplikasi $\mathrm{KNO}_{3}$ telah menunjukkan hasil yang nyata pada keseluruhan variabel pertumbuhan (Tabel 2, Tabel 3, Tabel 4, Tabel 5, Tabel 6). Hal tersebut dikarenakan umur bibit yang digunakan sudah mampu untuk menopang pertumbuhan tanaman apabila diberikan tambahan unsur hara dan air yang cukup pada saat fase perpindahan tanaman dari media satu ke media lainnya. Hal tersebut sesuai dengan petunjuk teknis pembibitan kelapa sawit oleh PPKS (2019) bahwa penambahan unsur hara yang sesuai baik dosis maupun jenisnya dengan ketersediaan air akan mampu untuk menopang pertumbuhan bibit dari media tanam pre nursery ke -main - nursery. Penambahan unsur hara yang sesuai seperti $\mathrm{KNO}_{3}$ mampu untuk meningkatkan pertumbuhan tanaman. Hal ini sesuai dengan penelitian Siregar et al. (2016), bahwa penggunaan pupuk $\mathrm{KNO}_{3}$ mampu untuk meningkatkan pertumbuhan tembakau varietas Deli yaitu pada fase vegetatif tanaman. Hal tersebut dikarenakan kandungan $\mathrm{KNO}_{3}$ seperti hara $\mathrm{N}$ dan $\mathrm{K}$ yang mampu untuk meningkatkan laju metabolisme tanaman selama proses fotosintesis. Pengaruh pengunaan $\mathrm{KNO}_{3}$ tersebut sesuai dengan hasil penelitian Usodri dan Utoyo (2021) bahwa penggunaan $\mathrm{KNO}_{3}$ mampu untuk menigkatkan seluruh parameter pengamatan tumbuh bibit kelapa sawit di 
Tabel 3. Rata - rata diameter bibit kelapa sawit $(\mathrm{cm})$ pada pengamatan 200 hari setelah pindah tanam.

\begin{tabular}{cccccc}
\hline \multirow{2}{*}{ Umur Bibit } & \multicolumn{5}{c}{ Pemupukan } \\
\cline { 2 - 6 } & $\mathrm{P} 1$ & $\mathrm{P} 2$ & $\mathrm{P} 3$ & $\mathrm{P} 4$ & $\mathrm{P} 5$ \\
\hline \multirow{2}{*}{$45 \mathrm{HST}$} & $2,57 \mathrm{c}$ & $2,84 \mathrm{~b}$ & $3,01 \mathrm{ab}$ & $3,06 \mathrm{ab}$ & $3,17 \mathrm{a}$ \\
& $\mathrm{A}$ & $\mathrm{A}$ & $\mathrm{A}$ & $\mathrm{A}$ & $\mathrm{A}$ \\
\multirow{2}{*}{$60 \mathrm{HST}$} & $2,42 \mathrm{c}$ & $2,60 \mathrm{bc}$ & $2,82 \mathrm{ab}$ & $2,91 \mathrm{a}$ & $3,00 \mathrm{a}$ \\
& $\mathrm{AB}$ & $\mathrm{B}$ & $\mathrm{AB}$ & $\mathrm{AB}$ & $\mathrm{AB}$ \\
$75 \mathrm{HST}$ & $2,33 \mathrm{c}$ & $2,48 \mathrm{bc}$ & $2,64 \mathrm{ab}$ & $2,76 \mathrm{a}$ & $2,84 \mathrm{a}$ \\
& $\mathrm{B}$ & $\mathrm{B}$ & $\mathrm{B}$ & $\mathrm{B}$ & $\mathrm{B}$ \\
& $2,28 \mathrm{~b}$ & $2,37 \mathrm{~b}$ & $2,50 \mathrm{~b}$ & $2,61 \mathrm{ab}$ & $2,75 \mathrm{a}$ \\
& $\mathrm{B}$ & $\mathrm{B}$ & $\mathrm{B}$ & $\mathrm{B}$ & $\mathrm{B}$ \\
\hline BNT & & \multicolumn{4}{c}{0,23} \\
\hline
\end{tabular}

Keterangan : Dua nilai tengah yang diikuti oleh huruf yang sama dinyatakan tidak berbeda nyata menurut uji BNT pada taraf $\alpha=5 \%$. Huruf kecil dibaca mendatar dan huruf besar dibaca menurun.

Tabel 4. Rata - rata luas daun kelapa sawit $(\mathrm{cm})$ pada pengamatan 200 hari setelah pindah tanam.

\begin{tabular}{cccccc}
\hline \multirow{2}{*}{ Umur Bibit } & \multicolumn{5}{c}{ Pemupukan } \\
\cline { 2 - 6 } & P1 & P2 & P3 & P4 & P5 \\
\hline \multirow{2}{*}{45 HST } & $278,43 \mathrm{e}$ & $285,43 \mathrm{~d}$ & $293,23 \mathrm{c}$ & $307,53 \mathrm{~b}$ & $322,17 \mathrm{a}$ \\
& $\mathrm{A}$ & $\mathrm{A}$ & $\mathrm{A}$ & & \\
\multirow{2}{*}{$60 \mathrm{HST}$} & $273,73 \mathrm{e}$ & $280,73 \mathrm{~d}$ & $288,53 \mathrm{c}$ & $302,83 \mathrm{~b}$ & $317,47 \mathrm{a}$ \\
& $\mathrm{AB}$ & $\mathrm{AB}$ & $\mathrm{AB}$ & & \\
$75 \mathrm{HST}$ & $269,53 \mathrm{e}$ & $276,53 \mathrm{~d}$ & $284,33 \mathrm{c}$ & $298,63 \mathrm{~b}$ & $313,27 \mathrm{a}$ \\
& $\mathrm{B}$ & $\mathrm{B}$ & $\mathrm{B}$ & & \\
& $266,83 \mathrm{e}$ & $273,83 \mathrm{~d}$ & $281,63 \mathrm{c}$ & $295,93 \mathrm{~b}$ & $310,57 \mathrm{a}$ \\
& $\mathrm{B}$ & $\mathrm{B}$ & $\mathrm{B}$ & \\
\hline BNT & \multicolumn{5}{c}{5,92} \\
\hline
\end{tabular}

Keterangan : Dua nilai tengah yang diikuti oleh huruf yang sama dinyatakan tidak berbeda nyata menurut uji BNT pada taraf $\alpha=5 \%$. Huruf kecil dibaca mendatar dan huruf besar dibaca menurun.

pre-nursery. Efektivitas penggunaan $\mathrm{KNO}_{3}$ sejalan dengan penelitian Usodri dan Utoyo (2021), penggunaan pupuk $\mathrm{KNO}_{3}$ dengan konsentrasi $4 \%$ mampu untuk meningkatkan tinggi bibit, diameter bibit, jumlah daun, luas daun dan tingkat kehijauan daun bibit kelapa sawit fase pre-nursery. Selain itu, efektivitas penggunaan pupuk $\mathrm{KNO}_{3}$ juga mampu untuk menigkatkan tinggi tanaman tembakau (Hutapea et al, . 2014); Peningkatan kehijauan daun dengan meningkatnya dosis pemberian $\mathrm{KNO}_{3}$ pada tanaman sorghum (Anggraini et al., 2018) sehingga mampu untuk mengoptimalkan pertambahan luas daun dan peningkatan jumlah daun tanaman (Setiawati et al., 2016). Heidari et al. (2014) menyatakan bahwa diameter tanaman French Tarragon juga bertambah seiring dengan penggunaan pupuk $\mathrm{KNO}_{3}$ sebagai dampak dari serapan usur kalium yang memiliki peranan dalam penyerapan nutrisi serta peningkatan hasil fotosintat tanaman(Hapsoh et al., 2020). Peningkatan parameter tumbuh pada bibit kelapa sawit dapat terjadi karena kandungan unsur hara dalam pupuk $\mathrm{KNO}_{3}$ yaitu $\mathrm{N}$ dan $\mathrm{K}$ meskipun dosis NPK Majemuk yang diberikan diturunkan menjadi 0,25 dosis rekomendasi sebagai upaya efisiensi pemupukan selama fase main-nursery. 
Kandungan unsur hara utama pada pupuk $\mathrm{KNO}_{3}$ yaitu $\mathrm{N}$ dan $\mathrm{K}$ dapat membantu memenuhi kebutuhan atau asupan nutrisi yang baik bagi pertumbuhan vegetatif kelapa sawit. Hal ini diduga karena penyerapan unsur hara yang diberikan dalam bentuk larutan lebih mudah diserap bagi tanaman melalui akar tanaman. Unsur Nitrogen memiliki peranan penting selama fase vegetatif tanaman yang berperan sebagai penyusun klorofil, komponen protein, dan sebagai penyusun komponen lain (Firmansyah dan Sumarni, 2013). Proses - proses tersebut akan mempengaruhi parameter pertumbuhan selama fase vegetatif tanaman yang berkaitan dengan tinggi tanaman, jumlah daun, luas daun, tingkat kehijauan daun, diameter batang hingga jumlah percabangan. Unsur hara nitrogen $(\mathrm{N})$ dapat diserap oleh tanaman dengan cara dirombak menjadi esensi asam amino, yang dalam proses selanjutnya akan membentuk protein dan asam nukleat. Selain itu, nitrogen juga menjadi bagian integral dari klorofil serta merupakan komponen utama yang membantu proses penyerapan cahaya yang dibutuhkan dalam fotosintesis (Barker dan Pilbeam, 2007).

Peranan unsur hara $\mathrm{K}$ pada pupuk $\mathrm{KNO}_{3}$ juga saling melengkapi dan memberikan peranan serta penunjang pertumbuhan tanaman. Kalium diserap

Tabel 5. Rata - rata tingkat kehijauan daun bibit kelapa sawit pada pengamatan 200 hari setelah pindah tanam.

\begin{tabular}{cccccc}
\hline \multirow{2}{*}{ Umur Bibit } & \multicolumn{5}{c}{ Pemupukan } \\
\cline { 2 - 6 } & $\mathrm{P} 1$ & $\mathrm{P} 2$ & $\mathrm{P} 3$ & $\mathrm{P} 4$ & $\mathrm{P} 5$ \\
\hline \multirow{2}{*}{$45 \mathrm{HST}$} & $74,77 \mathrm{~b}$ & $78,57 \mathrm{~b}$ & $81,13 \mathrm{ab}$ & $81,67 \mathrm{ab}$ & $82,97 \mathrm{a}$ \\
& $\mathrm{A}$ & $\mathrm{A}$ & $\mathrm{A}$ & $\mathrm{A}$ & $\mathrm{A}$ \\
\multirow{2}{*}{$60 \mathrm{HST}$} & $72,53 \mathrm{~b}$ & $76,37 \mathrm{~b}$ & $78,80 \mathrm{ab}$ & $80,20 \mathrm{ab}$ & $81,63 \mathrm{a}$ \\
& $\mathrm{AB}$ & $\mathrm{AB}$ & $\mathrm{AB}$ & $\mathrm{AB}$ & $\mathrm{AB}$ \\
& $71,53 \mathrm{~b}$ & $74,67 \mathrm{~b}$ & $76,30 \mathrm{ab}$ & $77,83 \mathrm{ab}$ & $79,87 \mathrm{a}$ \\
$75 \mathrm{HST}$ & $\mathrm{AB}$ & $\mathrm{AB}$ & $\mathrm{AB}$ & $\mathrm{AB}$ & $\mathrm{AB}$ \\
& $69,70 \mathrm{~b}$ & $73,27 \mathrm{ab}$ & $74,13 \mathrm{ab}$ & $76,37 \mathrm{ab}$ & $77,63 \mathrm{a}$ \\
\multirow{2}{*}{$90 \mathrm{HST}$} & $\mathrm{B}$ & $\mathrm{B}$ & $\mathrm{B}$ & $\mathrm{B}$ & $\mathrm{B}$ \\
\hline BNT & \multicolumn{5}{c}{}
\end{tabular}

$\overline{\text { Keterangan : Dua nilai tengah yang diikuti oleh huruf yang sama dinyatakan tidak berbeda nyata menurut uji BNT pada taraf }}$ $\alpha=5 \%$. Huruf kecil dibaca mendatar dan huruf besar dibaca menurun.

Tabel 6. Rata - rata jumlah pelepah bibit kelapa sawit pada pengamatan 200 hari setelah pindah tanam.

\begin{tabular}{cccccc}
\hline \multirow{2}{*}{ Umur Bibit } & \multicolumn{5}{c}{ Pemupukan } \\
\cline { 2 - 6 } & $\mathrm{P} 1$ & $\mathrm{P} 2$ & $\mathrm{P} 3$ & $\mathrm{P} 4$ & $\mathrm{P} 5$ \\
\hline \multirow{2}{*}{45 HST } & $6,33 \mathrm{c}$ & $7,33 \mathrm{bc}$ & $7,67 \mathrm{~b}$ & $9,33 \mathrm{a}$ & $9,67 \mathrm{a}$ \\
& $\mathrm{A}$ & $\mathrm{A}$ & $\mathrm{A}$ & $\mathrm{A}$ & $\mathrm{A}$ \\
\multirow{2}{*}{$60 \mathrm{HST}$} & $5,67 \mathrm{c}$ & $6,33 \mathrm{bc}$ & $7,00 \mathrm{~b}$ & $8,00 \mathrm{ab}$ & $8,67 \mathrm{a}$ \\
& $\mathrm{A}$ & $\mathrm{AB}$ & $\mathrm{AB}$ & $\mathrm{B}$ & $\mathrm{AB}$ \\
$75 \mathrm{HST}$ & $5,33 \mathrm{c}$ & $6,00 \mathrm{bc}$ & $6,67 \mathrm{~b}$ & $7,33 \mathrm{ab}$ & $8,33 \mathrm{a}$ \\
& $\mathrm{A}$ & $\mathrm{B}$ & $\mathrm{AB}$ & $\mathrm{B}$ & $\mathrm{B}$ \\
& $5,33 \mathrm{~b}$ & $5,67 \mathrm{~b}$ & $6,33 \mathrm{~b}$ & $7,00 \mathrm{ab}$ & $7,67 \mathrm{a}$ \\
& $\mathrm{A}$ & $\mathrm{B}$ & $\mathrm{B}$ & $\mathrm{B}$ & $\mathrm{B}$ \\
\hline
\end{tabular}

BNT

1,09

Keterangan : Dua nilai tengah yang diikuti oleh huruf yang sama dinyatakan tidak berbeda nyata menurut uji BNT pada taraf $\alpha=5 \%$. Huruf kecil dibaca mendatar dan huruf besar dibaca menurun. 
tanaman dalam bentuk $\mathrm{K}+$, ion ini disalurkan dari organ dewasa ke organ muda. Nitrogen diserap tanaman dalam bentuk NO3-, ion ini diperlukan untuk pertumbuhan tunas, pembentukan klorofil dan berpengaruh penting terhadap peningkatan hasil produksi (Koheri et al., 2015). Selain itu, Koten et al. (2012), menyatakan bahwa pemberian unsur $\mathrm{N}$ dan $\mathrm{K}$ yang tinggi pada media tanam akan mampu untuk meningkatkan pigem hijau (Klorofil) pada tanaman. Nitrogen dan Kalium juga secara langsung maupun tidak langsung akan terlibat dalam produksi zat aktif tanaman. Selain itu, unsur kalium (K) memliki fungsi atau peranan utama yaitu membantu pembentukan protein dan karbohidrat yang dapat dipakai oleh tanaman dalam proses metabolisme. Selain itu, peran unsur kalium (K) lainnya adalah memperkuat tubuh tumbuhan dan membuat daun, bunga dan buah sulit rontok. Kalium merupakan sumber tenaga tanaman (Adileksana et al., 2020). Pada tahapan selanjutnya akan terjadi peningkatan hasil fotosintat. Peningkatan hasil fotosintat akan berpengaruh pada pertumbuhan tanaman akibat dari meningkatnya hasil metabolisme dari unsur nitrogen dan kalium. Unsur hara $\mathrm{N}$ dan $\mathrm{K}$ lebih banyak dibutuhkan tanaman dibandingkan unsur hara lain, karena nitrogen dan kalium dapat digunakan dalam waktu yang relatif singkat digunakan untuk pertumbuhan vegetatif(Firmansyah et al., 2017). Pada akhirnya akan ada sinergisitas antara unsur hara $\mathrm{N}$ dan $\mathrm{K}$ yang saling berkaitan dalam menunjang proses pertumbuhan vegetatifbibitkelapa sawit di main-nursery. Laju pertumbuhan yang tinggi tersebut tidak hanya karena penggunaan pupuk $\mathrm{KNO}_{3}$, akan tetapi terdapat interaksi yang disebabkan karena media yang di pakai saat -main -nursery memiliki volume media tanam yang lebih luas. Hal tersebut ikut mempengaruhi kandungan unsur hara lebih banyak jika dibandingkan pada fase pre - nursery. Oleh sebab itu, proses pindah tanam yang lebih cepat yaitu pada 45 HST akan lebih mengefektifkan penyerapan hara dan pertumuhan tanaman. Hasil penelitian Fikri et al. (2013) menunjukkan bahwa penggunaan volume media yang lebih luas akan mempercepat laju pertumbuhan kelapa sawit pada setiap parameter pertumbuhannya. Ekaputra et al.(2016) juga menambahkan bahwa umur pindah tanam dapat mempengaruhi pertumbuhan vegetatif tanaman terutama pada tanaman jarak pagar dengan penggunaan komposisi media yang tepat. Proses pindah tanam yang lebih awal, memudahkan tanaman atau bibit untuk beradaptasi terhadap lingkungan lebih cepat dan lebih memudahkan akar untuk mengambil atau menyerap unsur hara lebih banyak. Akan tetapi, hal tersebut perlu diimbangi dengan pemupukan $\mathrm{KNO}_{3}$ sehingga tanaman menjadi lebih baik dan cepat dalam pertumbuhannya. Penggunaan media tanam dengan komposisi yang tepat dapat memacu pertumbuhan dikarenakan dalam media tanam tersebut terdapat unsur hara yang dibutuhkan oleh tanaman dalam proses pertumbuhan dan perkembangannya. Hal ni berkaitan dengan ketersediaan unsur hara yang sangat diperlukan saat pertumbuhan vegetatif yaitu unsur $\mathrm{N}$ dan $\mathrm{K}$.

\section{KESIMPULAN}

Kesimpulan yang dapat diambil pada penelitian ini adalah pemindah tanaman bibit kelapa sawit dapat dilakukan pada umur 45 hari setelah tanam dan 
pemberian pupuk $\mathrm{KNO}_{3}$ konsertrasi $4 \%$ dengan 0,25 dosis rekomendasi NPK majemuk utuk mengoptimalkan pertumbuhan pada pembibitan kelapa sawit di main-nursery.

\section{UCAPAN TERIMA KASIH}

Ucapan terima kasih kami sampaikan kepada Direktur Politeknik Negeri Lampung yang telah memberikan Dana DIPA Politeknik Sehingga terlaksananya penelitian ini dan Ketua Jurusan Budidaya Tanaman Perkebunan yang mensuport penelitian hingga akhir.

\section{DAFTAR PUSTAKA}

Adileksana, C., Yudono, P., Purwanto, B. H., \& Wijoyo, R. B. (2020). The Growth Performance of Oil Palm Seedlings in PreNursery and Main Nursery Stages as a Response to the Substitution of NPK Compound Fertilizer and Organic Fertilizer. Caraka Tani: Journal of Sustainable Agriculture, 35 (1): 89-97.

Anggraini, Puput Dian, Handayani, T. T., Yulianty, \& Zulkifli. (2018). Pengaruh Pemberian Senyawa KNO3 (Kalium Nitrat) Terhadap Pertumbuhan KEcambah Sorgum (Sorghum bicolor (L.) Moench). Jurnal Biologi Eksperimen dan keanekaragaman Hayati, 5(1): 37-42.

Barker AV \& DJ Pilbeam. 2007. Hand Book of Plant Nutrition. CRC Press. New York. 774 p.

Brhane, H., Mamo, T., Teka, K., \& Tejada Moral, M. (2017). Optimum potassium fertilization level for growth, yield and nutrient uptake of wheat
(Triticum aestivum ) in Vertisols of Northern Ethiopia . Cogent Food \& Agriculture, 3(1):

Direktorat Jendral Perkebunan. $2020 \mathrm{~S} \mathrm{t}$ a t i s t i k Perkebunan Indonesia Komoditas Kelapa Sawit 2017 - 2019. Buku Statistik Kelapa Sawit. Sekretariat Ditikrektorat Jendral Perkebunan. Jakarta. $68 \mathrm{hlm}$.

Du, Q., Zhao, X., Jiang, C., Wang, X., Han, Y., Wang, J., \& Yu, H. (2017). Effect of Potassium Deficiency on Root Growth and Nutrient Uptake in Maize (Zea mays L.). Agricultural Sciences, 08(11): 1263-1277.

Ekaputra, F., Supriyanta., \& Yudono, P. (2016). Pengaruh Komposisi Media dan Umur Pindah Tanam terhadap Pertumbuhan Awal Jarak Pagar (Jatropha curcas L.) dalam Pembibitan Metoda Cabutan. Vegetalika 5 (1): 32 - 45.

Fauzi, Y., Widyastuti Y. E., Wibawa I. S., \& Paeru R. H. 2012. Kelapa Sawit. Jakarta : Penebar Swadaya. $236 \mathrm{hlm}$.

Fauzi, W. R., \& E.T.S. Putra. (2019). Dampak Pemberian Kalium Dan Cekaman Kekeringan Terhadap Serapan Hara Dan Produksi Biomassa Bibit Kelapa Sawit (Elaeis gueenensis Jacq.). Jurnal Penelitian Kelapa Sawit, 27(1): 41-56.

Fikri, K., \& Yulia, A. E. (2013). Pengaruh Volume Media Dalam Polybag Terhadap Pertumbuhan Bibit Kelapa Sawit (Elaeis guineensis Jacq.). Jurnal Online Mahasiswa Fakultas Pertanian Universitas Riau 1 (1): 1-8.

Firmansyah, I. \& Sumarni. (2013). Pengaruh Dosis Pupuk N dan Varietas terhadap Ph Tanah, dap N-Total Tanah, Serapan N, dan Hasil Umbi Bawang Merah (Allium ascalonicum L.) pada Tanah Entisols-Brebes Jawa Tengah. Jurnal 
Hortikultura 23(4):358-364.

Firmansyah, I., Syakir, M., \& Lukman, L. (2017). The Influence of Dose Combination Fertilizer N, P, and $\mathrm{K}$ on Growth and Yield of Eggplant Crops (Solanum melongena L.)]. Jurnal Hortikultura.27(1): 69-78.

Hapsoh, H., Dini, I. R., Wawan, W., \& Sianipar, A. H. (2020). The Growth of Oil Palm Seedlings using a Combination Medium of Organic Oil Palm Empty Fruit Bunch and NPK Fertilizer at Main Nursery. Journal of Tropical Soils, 25(2): 61-69.

Heidari, S., Azizi, M., Soltani, F., \& Hadian, J. (2014). Foliar application of $\mathrm{Ca}\left(\mathrm{NO}_{3}\right)_{2}$ and $\mathrm{KNO}_{3}$ affects growth, essential oil content, and oil composition of French tarragon. Industrial Crops and Products, 62(3): 526-532.

Hutapea, A. S., Hadiastono, T., \& Martosudiro, M. (2014). Pengaruh Pemberian Pupuk Kalium (KNO3) Terhadap Infeksi Tobacco Mosaik Virus (TMV) pada Beberapa Varietas Tembakau Virginia (Nicotiana tabacum L.). Jurnal HPT, 2(1), 102-109.

Koheri, Anwar, Mariati, \& Toga, S. 2015. Tanggap Pertumbuhan Dan Produksi Bawang Merah (Allium ascalonicum L.)Terhadap Waktu Aplikasi Dan Konsentrasi Pupuk KNO3. Jurnal Agroekoteknologi. 3(1) : 206 - 213.

Koten, B. B., R.D. Soetrisno., N. Ngadiyono., dan B. Suwigyo. (2012). Produksi Tanaman Sorgum (Sorghum bicolor (L.) Moench) Varietas Lokal Rote Sebagai Hijauan Pakan Ruminansia Pada Umur Panen Dan Dosis Pupuk Urea Yang Berbeda. Buletin Peternakan, 36(3), 150-155.

Kurniawan, A., T. Islami., \& Koesriharti. (2017). Pengaruh Aplikasi Pupuk N Dan K Terhadap
Pertumbuhan Dan Hasil Tanaman Pakcoy (Brassica rapa var. chinensis) Flamingo F1. Jurnal Produksi Tanaman 5 (2) : 281-289.

Maruli. (2012). Paduan Lengkap Pengelolaan Kebun dan Pabrik Kelapa Sawit. Agromedia. Jakarta. 181hlm.

Mastur, Syafaruddin, \& M.Syakir. 2015. Peran dan Pengelolaan Hara Nitrogen pada Tanaman Tebu Untuk Peningkatan Produktivitas Tebu. Persefektif 14 (2) : 73 - 86.

PPKS. 2019. Pedoman Petunjuk Teknis Pembibitan Kelapa Sawit. Medan. Sumatera Utara. 10hlm.

Saputra. D., S. Elza., \& Yosepa, S. (2016). Pematahan Dormansi Benih Kelapa Sawit (Elaeis guineensis Jacq.) Dengan Berbagai Konsentrasi Kalium Nitrat (KNO3) Dan Pengaruhnya Terhadap Pertumbuhan Bibit Pada Tahap Pre Nursery. J. JOM Faperta, 4(2), 4-14.

Siregar.R.P., Ginting. J., \& Meiriani. (2018). Pertumbuhan dan Produksi Tembakau Deli (Nicotiana tabacum L.) terhadap Pemberian Pupuk KNO3 dan Pupuk Organik Cair Urin Kelinci. Jurnal Agroteknologi FPUSU 6(2): 236 - 243.

Usodri. K.S., \& B. Utoyo. (2021).Pengaruh Penggunaan $\mathrm{KNO}_{3}$ pada Pertumbuhan Bibit Kelapa Sawit (Elaeis guineensis Jack) Fase Pre-Nursery. Jurnal Agrinika 5 (1) : 1-9.

Sukmawan. Y., Riniarti. D., \& Utoyo. B. (2018). Pembibitan Kelapa Sawit. UP Politeknik Negeri Lampung. Lampung

Zhang, A. Q., Sechenchogt, Wang, I. H., \& Y. N, W. (2015). Effects of K Stress On Growth and P Uptake Of Different Genotypes Maize. Hubei Agricultural Sciences, 54, 292-295. 